\title{
HUBUNGAN ANTARA TINGKAT STRES DENGAN PERILAKU PROKRASTINASI PADA MAHASISWA FKIP UHO YANG SEDANG MENYUSUN SKRIPSI
}

\author{
Indah Ayu Octafiani', Aspin ${ }^{2}$, Sitti Mikarna Kaimuddin ${ }^{3}$ \\ Program Studi Psikologi \\ Fakultas Keguruan dan Ilmu Pendidikan, Universitas Halu Oleo \\ Email : Indahayuoctafiani@gmail.com
}

\begin{abstract}
ABSTRAK
Stres bisa menjadi pemicu munculnya prokrastinasi, dimana prokrastinasi merupakan suatu kecenderungan perilaku dalam diri individu untuk menghabiskan waktu, menunda, dan secara sengaja tidak segera mengerjakan sesuatu yang seharusnya diselesaikan. Dalam hal ini stres yang dialami mahasiswa dapat membuat mahasiswa tidak termotivasi dan malas untuk mengerjakan skripsi sehingga pada akhirnya melakukan prokrastinasi. penelitian ini bertujuan untuk mengetahui hubungan antara tingkat stres dengan perilaku prokrastinasi pada mahasiswa FKIP UHO yang sedang menyusun skripsi. Penelitian ini menggunakan metode kuantitatif dengan desain cross sectional. Sampel dalam penelitian ini adalah mahasiswa FKIP UHO yang sedang menyusun skripsi berjumlah 127 mahasiswa yang dipilih berdasarkan teknik puprposive sampling. Tingkat stres diukur dengan menggunakan Skala DASS 42 yang telah di modifikasi dan perilaku prokrastinasi dengan Tuckman Procrastination Scale versi adaptasi. Analisis data menggunakan teknik korelasi Pearson Product Moment yang menunjukkan nilai koefisien korelasi $(\mathrm{r})=0,644$ dengan nilai signifikansi $(\mathrm{p})=0,000(\mathrm{p}<0,05)$ sehingga dapat diartikan bahwa terdapat hubungan positif yang kuat antara tingkat stres dengan perilaku prokrastinasi pada mahasiswa FKIP UHO yang sedang menyusun skripsi.
\end{abstract}

Kata Kunci: Tingkat Stres, Perilaku Prokrastinasi

\begin{abstract}
Stress can be a trigger for the emergence of procrastination, where procrastination is a behavioral tendency in individuals to spend more time, delay, and deliberately not immediately doing something that should be resolved. The stress experienced by students can make them unmotivated and lazy to work on their undergraduatethesis so that in the end they do procrastination. This research aimedto determine the relationship between stress levels with procrastination behavior in students of FKIP UHO who are writing theirundergraduate thesis. This research uses quantitative methods with cross sectional design. Sample in this researchisstudents of FKIP UHO who were preparing their mini thesis, with total sampling are 127 students that have been selected based on purposive sampling techniques. The stress level was measured using a modified DASS 42 scale and procrastination behavior with the adapted version of the Tuckman Procrastination Scale. Data analysis using Pearson Product Moment correlation technique that shows the correlation coefficient $(r)=0.644$ with a significance value $(p)=0,000(p<0.05)$ so that it can be interpreted that there is a strong positive relationship between stress levels with procrastination behavior in students of FKIP UHO who is preparing undergraduatethesis.
\end{abstract}

Keywords: Stress Level, Procrastination Behavior 


\section{Pendahuluan}

Mahasiswa adalah individu yang belajar pada tingkat perguruan tinggi untuk mempersiapkan dirinya bagi suatu keahlian tingkat sarjana yang dalam mengerjakan fungsinya, mahasiswa memiliki tuntutan akademik (Budiman dalam Yuliana, 2016). Tuntutan akademik yang dimaksud adalah belajar, mengerjakan tugas penting yang berkaitan dengan akademis, salah satunya yaitu menyelesaikan skripsi (Akmal, 2013), guna melengkapi syarat memperoleh gelar sarjana.

Pendidikan Strata satu ditempuh selama kurang lebih dalam kurun waktu 4 tahun di perguruan Tinggi (Ali, 2009). Tetapi dalam praktiknya mahasiswa tidak selalu dapat menuntaskan studinya dalam rentang waktu pada umumnya yakni empat tahun pada studi strata satu. Selain itu dari data mahasiswa FKIP UHO yang sedang menyususn skripsi, memperlihatkan sebanyak 3.215 Mahasiswa FKIP UHO yang masih berstatus mahasisswa aktif dan berada pada tahap penyusunan skripsi. Umumnya, proses pengerjaan skripsi, mahasiswa diberi waktu selama satu semester atau kurang lebih sekitar enam bulan (Sari, 2014). Namun, kenyataannya masih banyak mahasiswa yang menyelesaikan skripsi lebih lama dari seharusnya. Hal ini di karenakan pada saat mengerjakan tugas skripsi, mahasiswa akhir akan menghadapi berbagai hambatan dalam menyusun skripsi termasuk diantaranya kesulitan mencari judul, kurangnya kemampuan menulis, dan kesulitan mencari literatur yang kemudian menimbulkan perasaan tertekan pada diri mahasiswa (Gunawati, Hartati \& Listiara, 2006).

Iswidharmanjaya dan Enterprise (dalam Sari, 2013) menambahkan bahwa skripsi sering kali menjadi hal yang menakutkan bagi sebagian mahasiswa akhir. Sehingga dengan adanya perasaan takut gagal dan ketidaksukaan pada tugas, dapat menyebabkan terjadinya prokrastinasi pada mahasiswa (Solomon \& Rothblum, 1984).

Tuckman (1991) mengartikan prokrastinasi sebagai kecendrungan dalam menghabiskan waktu, menunda dan secara sengaja tidak segera mengerjakan sesuatu yang seharusnya diselesaikann. Hasil penelitian yang dilakukan Ellis dan Knaus (dalam Janssen \& Carton, 1999) tentang prokrastiansi pada mahasiswa menyebutkan bahwa terdapat $95 \%$ mahasiswa kerap melakukan prokrastiansi terhadap tugas-tugas akdemiknya. Hasil penelitian berikut mengungkapkan hal-hal lain yang dapat membuat seseorang melakukan prokrastinasi akademik diantaranya adalah kurangnya kemampuan dalam mengontrol diri (Aini \& Mahardayani, 2011), pesimisme (Nugroho, Machmuroch, \& Karyanta 2015), takut akan kegagalan (Haghbin, McCaffrey, \& Pychyl, 2012), depresi (Anggawijaya, 2013), cemas (Milgram \& Toubiana, 1999), lanjut Ferrari, Johnson, dan McCown (1995) memaparkan bahwa salah satu faktor yang menyebabkan prokrastinasi adalah faktor internal yang diantaranya termasuk stres.

Stres merupakan suatu kondisi waspada dan tegang yang dirasakan terusmenerus serta mudah sedih atau frustasi (Lovibond \& Lovibond, 1995).

Kondisi stres akan semakin diperparah dengan adanya tuntutan dalam menyelesaikan skripsi (Rohmah, 2006). Beberapa penyebab munculnya stres pada mahasiswa dalam menyusun skripsi adalah rendahnya keyakinan pada kemampuan diri serta kesulitan atau hambatan yang dialami dalam proses penyusunan skripsi.

Rumiani (2006) menjelaskan bahwa stres pada mahasiswa dapat bersumber dari beberapa hal diantaranya masalah keuangan, beban tugas, ujian dan masalah interaksi dengan teman. Rohmah (2007) juga menambahkan stres yang dialami mahasiswa dalam menyusun skripsi dapat mengakibatkan munculnya gejala emosi dan gejala fisik, diantaranya perasaan jengkel karena dosennya sulit di temui dan tidak menepati janji, cemas, pesimis, mudah marah, mudah putus asa, merasa tegang dan tertekan, malu, sering menangis dan linglung. Sedangkan gejala fisik yang muncul antara lain tidak nafsu makan, tidak bisa tidur, muncul jerawat, sakit pinggang, 
migraine, sakit perut, dan gemetar waktu akan bimbingan.

Agung dan Budiani (2013) juga menambahkan bahwa stres yang dialami mahasiwa dalam menyusun sripsi dapat memunculkan reaksi perilaku negatif dalam dirinya yang berkaitan dengan skripsi diantaranya menghindari pengerjaan skripsi, melakukan aktivitas lain yang dianggap menarik, dan menundah-nunda atau prokrastinasi. Akibatnya individu yang cenderung melakukan prokrastinasi akan mengalami stres secara terus menerus (Beutel et al, 2016). Dimana, prokrastinasi merupakan salah satu cara yang dilakukan untuk menghindari tekanan dan usaha yang dibutuhkan dalam menyelesaikan suatu tugas sehingga dapat dikatakan bahwa prokrastinasi merupakan salah satu cara yang digunakan untuk mengatasi stres (Veresova, 2013). Penelitian ini di dukung oleh hasil penelitian yang dilakukan Andarini dan Fatma (2013) yang menyatakan bahwa ada hubungan positif antara stres dan prokrastinasi akademik, artinya semakin tinggi stres seseorang maka semakin tinggi perilaku prokrastinasi dalam dirinya.

Berbeda halnya dengan beberapa penelitian lainnya yang menyatakan hal sebaliknya yaitu tidak terdapat hubungan antara stres dan prokrastinasi, diantaranya penelitian yang dilakukan oleh Rumiani (2006) yang menyatakan bahwa stres tidak memiliki korelasi dengan prokrastinasi akademik hal ini dikarenakan prokrastinasi banyak dipengaruhi oleh faktor internal (motivasi berprestasi).

Peneltian tentang hubungan antara tingkat stres dengan perilaku prokrastinasi sudah banyak dilakukan di berbagai perguruan tinggi di Indonesia, yang hasilnya masih terdapat kesenjangan penelitian dalam menjelaskan ada tidaknya hubungan antara tingkat stres dengan perilaku prokrastinasi, menjadikan hubungan kedua variabel tersebut menarik untuk dilakukan penelitian lanjutan pada mahasiswa Fakultas Keguruan dan Ilmu Pendidikan Universitas Halu Oleo, yang sedang menyusun skripsi. Alasan peneliti memilih judul ini karena perbedaan tempat penelitian serta perbedaan subjek yang diteliti. Selain itu juga karena peneliti melihat masih minimnya penelitian yang berkaitan dengan tingkat stres tersebut.

Fenomena di lapangan juga memperlihatkan adanya penundaan waktu kelulusan pada mahasiswa untuk menyelesaikan studinya di perguruan tinggi. Hal tersebut mengarah pada apa yang di sebut dengan prokrastinasi.

Berdasarkan permasalahan tersebut maka peneliti mengadakan penelitian dengan judul "Hubungan antara tingkat stres dengan perilaku prokrastinasi pada mahasiswa FKIP UHO yang sedang menyusun skripsi”.

Penelitian ini bertujuan untuk mengetahui hubungan antara tingkat stres dengan perilaku prokrastinasi pada mahasiswa FKIP UHO yang sedang menyusun skripsi.

Manfaat dalam penelitian ini terdiri dari manfaat teoritis dan manfaat praktis, yakni sebagai berikut:

\section{Manfaat Teoritis}

Diharapkan dapat memeperkaya kajian teori dan riset psikologi, khusunya dalam psikologi pendidikan.

\section{Manfaat praktis}

a. Dapat memberikan informasi kepada pihak Fakultas Ilmu Pendidikan Universitas Halu Oleo mengenai hubungan antara tingkat stres dengan perilaku prokrastinasi. Sehingga dapat membantu meminimalisir perilaku menunda-nunda dengan caranya sendiri.

b. Bagi Mahasiswa, dapat memberikan informasi mengenai hubungan antara tingkat stres dengan perilaku prokrastinasi pada mahasiswa FKIP UHO yang sedang menyusun skripsi sehingga dapat menjadi bahan pertimbangan untuk menghindari stres sehingga dapat mencegah terjadinya kecenderungan prokrastinasi.

c. Bagi Peneliti selanjutnya, diharapkan hasil penelitian ini dapat menjadi 
salah satu bahan acuan yang juga mengkaji tentang tingtkat stres dan perilaku prokrastinasi. Dengan demikian, hasil penelitian ini dengan yang selanjutnya bisa saling melengkapi dan saling menutupi kekurangannya masing-masing.

\section{Metode Peneltian}

Penelitian ini menggunakan metode kuantitatif dengan desain cross sectional. Sampel dalam penelitian ini adalah mahasiswa FKIP UHO yang sedang menyusun skripsi berjumlah 127 mahasiswa yang dipilih berdasarkan teknik puprposive sampling. Tingkat stres diukur dengan menggunakan Skala DASS 42 yang telah di modifikasi dan perilaku prokrastinasi dengan Tuckman Procrastination Scale versi adaptasi.

Dalam penelitan ini data dianalisis dengan menggunakan analisis Correlation Pearson product moment, yakni uji statistik yang digunakan untuk menguji hipotesis bila kedua uji asumsi terpenuhi yaitu data berdisitribusi normal dan linear. Perhitungan analisis dilakukan dengan meggunakan bantuan program SPSS Versi 21.0 for Windows.

\section{Hasil Peneltian dan Pembahasan Hasil Penelitian}

1. Uji Asumsi

a. Uji Normalitas

Tabel 1. Hasil Uji Normalitas Tingkat Stres dan Perilaku Prokrastinasi

\begin{tabular}{lcc}
\hline \multicolumn{1}{c}{ Variabel } & Signifikansi & Keterangan \\
\hline $\begin{array}{l}\text { Tingkat } \\
\text { Stres }\end{array}$ & 0.307 & $\begin{array}{l}\mathrm{P} \geq 0,05 \\
(\text { Normal) }\end{array}$ \\
\hline $\begin{array}{l}\text { Perilaku } \\
\text { Prokrastinasi }\end{array}$ & 0.819 & $\begin{array}{l}\mathrm{P} \geq 0,05 \\
(\text { Normal) }\end{array}$ \\
\hline
\end{tabular}

Uji normalitas terhadap variabel tingkat stres memperoleh nilai signifikansi $(\mathrm{p})=0.307>0.05$, nilai tersebut memiliki arti bahwa variabel tingkat stres berdistribusi normal. Selanjutnya, hasil uji normalitas variabel perilaku prokrastinasi di ketahui memiliki nilai signifikansi (p) $=0.819>0.05$, sehingga berarti bahwa variabel prokrastinasi juga berdistribusi normal

b. Uji Linearitas

Tabel 2. Hasil Uji Linearitas Tingkat Stres dan Perilaku Prokrastinasi

\begin{tabular}{lccc}
\hline Variabel & & $\mathrm{F}$ & $\begin{array}{c}\text { Signifik } \\
\text { asi }\end{array}$ \\
\hline $\begin{array}{l}\text { Perilaku } \\
\text { Prokrastin } \\
\text { asi }\end{array}$ & $\begin{array}{c}\text { (Combine } \\
d)\end{array}$ & 3.879 & .000 \\
\cline { 2 - 4 } $\begin{array}{l}\text { Tingkat } \\
\text { Stres }\end{array}$ & $\begin{array}{c}\text { Deviation } \\
\text { From } \\
\text { Linearity }\end{array}$ & 127.536 & .000 \\
\hline
\end{tabular}

Uji Linearitas data dengan menggunakan Test for Linearity pada program SPSS 20.0 menunjukkan nilai signifikansi sebesar 0.000 . Nilai ini lebih kecil dari 0,05 sehingga data tersebut menunjukkan bahwa terdapat hubungan yang linear antara variabel tingkat stres dengan perilaku prokrastinasi.

2. Uji Hipotesis

Tabel 3. Uji Korelasi korelasi Pearson Product Moment

\begin{tabular}{lll}
\hline Variabel & $\begin{array}{l}\text { Korelasi } \\
\text { Pearson }\end{array}$ & Signifikansi \\
\hline Tingkat Stres & 0.644 & 0.000 \\
\hline $\begin{array}{l}\text { Perilaku } \\
\text { Prokrastinasi }\end{array}$ & 0.644 & 0.000 \\
\hline
\end{tabular}

Hasil analisis menunjukkan nilai signifikansi $(\mathrm{p})=0.000$ lebih kecil dari $0.05(\mathrm{p}<0.05)$ yang menunjukkan bahwa tingkat stres dan perilaku prokrastinasi memiliki korelasi. Nilai korelasi pearson sebesar 0.644 hal ini menunjukkan korelasi positif dengan kekuatan korelasi kuat. Hubungan tersebut mengartikan bahwa semakin tinggi intesitas tingkat stres maka akan semakin tinggi intesitas perilaku prokrastinasi, begitupun sebaliknya. 


\section{Pembahasan}

Berdasarkan hasil analisis data diketahui bahwa ada hubungan yang positif antara tingkat stres dengan perilaku prokrastinasi, hal ini di tunjukkan oleh nilai korelasi pearson sebesar 0.644 yang menunjukkan kekuatan korelasi kuat. Dengan demikian, hipotesis yang diajukan di terima yaitu ada hubungan antara tingkat stres dengan perilaku prokrastinasi pada mahasiswa FKIP UHO yang sedang menyusun skripsi.

Temuan ini mendukung beberapa penelitian terdahulu yang menunjukkan bahwa stres berkaitan dengan prokrastinasi, diantaranya penelitian yang dilakukan oleh Handayani, Suharman dan Abdullah (2016) yang menemukan bahwa stres bisa menjadi pemicu munculnya prokrastinasi akademik dimana mahasiswa yang kurang yakin akan kemampuan yang dimiliknya dapat mengakibatkan dirinya mudah mengalami stres saat menghadapi tugas, termasuk skripsi. Retno, Handayani dan Abdullah (2017) juga menambahkan bahwa mahasiswa yang merasa terbebani dan tidak tenang dalam mengerjakan skripsi akan mengalami stres yang pada akhirnya membuatnya malas dan kehilangan motivasi untuk menyelesaikan skripsi sehingga muncul perilaku prokrastinasi pada mahasiswa.

Banyak masalah yang harus dihadapi mahasiswa dalam menyusun skripsi seperti kesulitan mencari judul, kurangnya kemampuan menulis, dan kesulitan mencari literatur yang kemudian menimbulkan perasaan tertekan pada diri mahasiswa (Gunawati, Hartati \& Listiara, 2006).

Sebagian mahasiswa akhir, secara khusus akan mengalami stres akibat tertekan karena waktu yang semakin sempit untuk menyelesaikan masa studinya dan juga tekanan dari keluarga serta lingkungan yang selalu bertanya mengenai kelulusan (Damayanti, 2013).

Secara deskriptif, hasil penelitian ini juga memperlihatkan nilai korelasi pearson yakni sebesar 0,644 yang menunjukkan korelasi positif dengan kekuatan korelasi kuat yang mengartikan bahwa semakin tinggi tingkat stres maka akan semakin tinggi intensitas perilaku prokrastinasi, begitupun sebaliknya.

Adanya variasi data hasil penelitian tingkat stres dan perilaku prokrastinasi pada mahasiswa FKIP UHO yang sedang menyusun skripsi, seperti tingginya tingkat stres pada mahasiswa prokrastinasi rendah atau sebaliknya, hal ini disebabkan karena adanya faktor lain, yakni kemampuan individu dalam beradaptasi (Lazarus dan Folkman, 1984), dan usia (Papalia, Old dan Feldman, dalam Wahyuningsih, 2014).

Selain itu pada perilaku prokrastinasi, faktor lain yang dapat menyebabkan adanya variasi data yang tidak sesuai dengan hasil penelitian antara lain , usia (Ferrari, Johnson \& McCown, 1995), dan durasi terpaparnya sumber stres (Lazarus \& Folkman, 1984).

Secara empiris, hipotesis dalam penelitian ini telah terbukti, dimana semakin tinggi tingkat stres maka semakin tinggi perilaku prokrastinasi, hal ini berdasarkan hasil uji hipotesis yang memperlihatkan tingkat hubungan yang kuat, dimana nilai korelasi pearson adalah 0,644 yang artinya apabila mahasiswa mengalami stres ketika sedang menyusun skripsi maka mahasiswa akan memiliki kecenderungan untuk menunda pengerjaan skripsi sebagai upaya untuk mengatasi masalah yang mahasiswa hadapi yakni dalam proses penyusunan skripsi. Jadi dapat disimpulkan bahwa tingkat stres berkorelasi dengan perilaku prokrastinasi

\section{Kesimpulan dan Saran Kesimpulan}

Berdasarkan hasil penelitian maka dapat disimpulkan bahwa hipotesis diterima yaitu ada hubungan antara tingkat stres dengan perilaku prokrastinasi pada mahasiswa FKIP UHO yang sedang menyusun skripsi. lebih jauh lagi hasil penelitian menemukan hubungan positif antara tingkat stres dengan perilaku prokrastinasi dengan nilai korelasi pearson sebesar 0.644 yang menunjukkan kekuatan korelasi kuat. Dengan demikian dapat diartikan bahwa semakin tinggi tingkat stres 
maka akan semakin tinggi perilaku prokrastinasi, begitupun sebaliknya.

\section{Saran}

1. Bagi Mahasiswa.

a. Diharapkan kepada mahasiswa yang berada pada kondisi stres agar dapat mengelola stres dengan baik dengan mengadakan diskusi terbuka membahas kesulitan-kesulitan yang dialami dalam menyusun skripsi dan cara mengatasinya serta saling membantu sesama mahasiswa yang sedang menyelesaikan skripsi.

b. Diharapkan pula para mahasiswa yang berada pada intensitas prokrastinasi yang sedang, tinggi, dan sangat tinggi agar dapat mengelola waktu dengan baik sehingga tidak menunda-nunda dalam mengerjakan skripsi, dimana hal tersebut dapat dilakukan dengan cara membuat tenggat waktu untuk mencapai tiap tahapan penyusunan skripsi, sedangkan kepada mahasiswa yang berada pada intensitas prokrastinasi yang rendah diharapkan dapat terus mempertahankan perilaku positifnya.

2. Bagi Pihak FKIP UHO.

Diharapkan dapat memberikan motivasi kepada para mahasiswa sehingga kedepannya para mahasiswa dapat mempertahankan perilaku positifnya dan mengelola waktu dalam menyususn skripsi lebih baik lagi.

3. Bagi Peneliti Selanjutnya.

a. Perlu dilakukan penelitian yang lebih lanjut, terkait dengan faktor risiko lain pada sampel penelitian

b. Dapat melibatkan subjek penelitian dengan rentang usia lainnya dan tidak berfokus pada skripsi saja

c. Hendaknya memperluas populasi penelitian, atau juga dapat memperbanyak jumlah sampel untuk penelitian yang akan datang.

d. Menggunakan metode kualitatif untuk mendapatkan data yang lebih mendalam.

\section{Daftar Pustaka}

Agung, G., \& Budiani, M. S. (2013). Hubungan kecerdasan emosi dan self efficacy dengan tingkat stres mahasiswa yang sedang mengerjakan skripsi. Character, 1(2), 1-6.

Aini, A. N., \& Mahardayani, I. H. (2011). Hubungan Antara Kontrol Diri Dengan Prokrastinasi Dalam Menyelesaikan Skripsi Pada Mahasiswa Universitas Muria Kudus. Jurnal Psikologi Pitutur, 1(2), 65-71.

Akmal, V. E. (2013). Perbedaan Prokrastinasi Akademik Berdasarkan Jenis-Jenis Kelamin Dengan Mengontrol Manajemen Waktu Pada Mahasiswa Universitas Muria Kudus. Jurnal Psikologi Pitutur, 1(2), 65-71.

Ali, M. (2009) Pendidikan Untuk Pembangunan Nasional: Menuju Bangsa Indonesia Yang Mandiri Dan Berdaya Saing Tinggi. Jakarta: Grasindo.

Andarini, S. R., \& Fatma, A. (2013). Hubungan Antara Distress Dan Dukungan Sosial Dengan Prokrastinasi Akademik Pada Mahasiswa Dalam Menyusun Skripsi. Talenta Psikologi, 2(2), 159-179.

Anggawijaya, S. (2013). Hubungan Antara Depresi Dan Prokrastinasi Akademik. Jurnal Ilmiah Mahasiswa Univeritas Surabaya, 2(2), 1-12.

Beutel, M., Klein , E., Aufenager, S., Brahler, E., Dreier, M., \& Muller, K. et al. (2016). Procrastination, Distress And Life Satisfaction Across The Age Range A German Representive Community Study. Plos One, 11(2).

Damayanti, Y. (2013). Perbedaan Tingkat Stres Sebelum Dan Setelah Pelatihan Manajemen Stres Pada Mahasiswa Tingkat Akhir Di Asrama Aceh. 
EMPATHY Jurnal Fakultas Psikologi. 2(1).

Ferrari, J. R., Johnson, J. L., \& McCown, W. G. (1995). Procrastination And Task Avoidance. New York: Plennum Press.

Gunawati, R., Hartati, S., \& H, Listiara. A. (2006). Hubungan Antara Efektifitas Komunikasi Mahasiswa-Dosen Pembimbing Utama Skripsi dengan Stres Dalam menyusun Skripsi Pada Mahasiswa Program Studi Psikologi Fakultas Kedokteran Universitas Diponegoro. Jurnal Psikologi, 2(3), 93-115.

Haghbin, McCaffrey, A., \& Pychyl, T. (2012) The Complexity of the Relation between Fear of Failure and Procrastination. Journal of Rational Emotive \& Cognitive-Behavior Therapy, 30(4), 249-263.

Handayani, S. W. R. I., \& Suharnan., Abdullah, A. (2016) Hubungan stres dengan prokrastinasi pada mahasiswa. Psikovidya,1(20), 32-39.

Janssen, T. \& Carton, J. (1999). The Effects of Locus of Control and Task Difficulty on Procrastination. The Journal Of Genetic Psychology, 160(4), 436-442.

Lazarus, R., \& Folkman, S. (1984). Stress, Appraisal, and Coping. New York. Springer Publishing Company. Lovibond, P.F., \& ovibond, S. H. (1995). The Structure of Negative Emotional States: Comparation Of The Depression Anxiety Stress Scales (DASS) with the Beck Depression and Anxiety Inventories. Behavior Research and Therapy, 33(3), 335343.

Nugroho, J. A., Machmuroch., \& Karyanta, N. A. (2015). Hubungan Antara
Pesimisme Dengan Prokrastinasi Akademik Dalam Menyelesaikan Skripsi Pada Mahasiswa Program Studi Psikologi Universitas Sebelas Maret Surakarta. Jurnal Ilmiah Psikologi Candrajiwa, 3(4), 264-274.

Retno, S., Handayani, I., \& Abdullah, A. (2017) Hubungan stres dengan prokrastinasi pada mahasiswa. Psikovidya,1(20), 32-39Riyanto, A. (2011). Aplikasi Metodologi Penelitian Kesehatan. Yogyakarta : Nuha Medika.

Rohmah, F. A. (2006). Pengaruh Diskusi Kelompok Untuk Menurunkan Stres Pada Mahasiswa Yang Sedang Skripsi. Humanitas: Indonesian Psyhological Journal, 3(1), 50-62.

Rohmah, F. A. (2007). Efektivitas Diskusi Kelompok Dan Pelatihan Efikasi Diri Untuk Menurunkan Stres Mahasiswa Yang Sedang Skripsi. Humanitas, 4(1), 59-67.

Rumiani. (2006). Prokrastinasi Akademik Ditinjau Dari Motivasi Berprestasi Dan Stres Mahasiswa. Jurnal Psikologi universitas diponegoro, 3(2), 27-48.

Sari, D. N. (2013) Hubungan stres terhadap guru dengan prokrastinasi akademik pada siswa SMA Muhammadiyah 2 Yogyakarta. Empathy, 1(2), 15-35.

Sari, S. Z. (2014). Hubungan Dukungan Sosial Orangtua, Teman Dan Dosen Pembimbing Skripsi Dengan Prokrastinasi Akademik Dalam Mengerjakan Skripsi Pada Mahasiswa Fakultas Psikologi Angkatan 2009-2010 Universitas Islam Negeri Malang. Malang: Fakultas Psikologi Universitas Islam Negeri Maulana Malik Ibrahim Malang. 
Solomon, L.J., \& Rothblum, E. D. (1984) Academic Procrastination: Frequency and Cognitive-Behavioral Correlates. Journal of Counseling Psychology, 31(4), 503-509.

Tuckman, B. W. (1991). The Development and Concurrent Validity Of The Procrastination Scale. Educational and Psychological Measurement, 51(2), 473-480.

Veresova, M. (2013). Procrastination, Stress And Coping Among Primary School Teachers. Procedia - Social And Behavioral Sciences, 106, 2131-2138.

Wahyuningsih, M.A.A (2014). Perbedaan Tingkat Coping Stres Berdasarkan Presepsi Polah Asuh Orangtua Pada Remaja Awal. Yogyakarta : Program Studi Psikologi Fakultas Psikologi Universitas Sanata Dharma.

Yuliana, K. (2016). Hubungan Antara Kecerdasan Emosional Dengan Stres Mahasiswa Dalam Proses Penyusunan Skripsi. Semarang: Fakultas Psikologi Universitas Katolik Soegijapranata. 